\title{
MAKASSAR SMART TRANSPORTATION: Penerapan Mamminasata Apps dan Mamminasata Card guna optimalisasi Bus Rapid Transit (BRT) Kota Makassar
}

\author{
Irawati Ismail Ali \\ Fakultas Ekonomi dan Bisnis, Universitas Hasanuddin \\ Email: irawatibantaeng21@gmail.com \\ Muh. Imadudin Akmal \\ Fakultas Ekonomi dan Bisnis, Universitas Hasanuddin \\ Email:muh.imadudin@gmail.com
}

Ayu Latifah Alfisyahrin

Fakultas Ekonomi dan Bisnis, Universitas Hasanuddin

Email:ayulatifah90@yahoo.com

Nur Fajar Indrawan

Fakultas Ekonomi dan Bisnis, Universitas Hasanuddin

Email: nurfajarindrawan@gmail.com

Shinta Dewi Sugiharti Tikson

Dosen Fakultas Ekonomi dan Bisnis, Universitas Hasanuddin

Email:shintatikson@gmail.com

\begin{abstract}
Abstrak: Transportasi publik seperti Bus Rapid Transit (BRT) adalah solusi popular yang digunakan di kota-kota besar di Indonesia untuk mengatasi kemacetan lalu lintas. Contohnya, Jakarta dengan bus Trans Jakarta, Yogyakarta dengan Bus Trans Yogyakarta dan Makassar dengan BRT Mamminasata. Bus rapid Transit (BRT) mulai beroperasi di Kota Makassar pada Maret 2014 yang dikenal dengan nama Maminassata, namun penggunaannya belum optimal. Hal ini dikarenakan ada dua permasalahan utama Bus Rapid Transit (BRT) Mamminasata yaitu (1) ketidakpastian waktu tiba ke halte dan waktu tempu sampai tujuan, dan (2) sistem pembayaran dan sistem pengendalian operasional BRT Mamminasata. Maka dari itu, Makassar Smart Transportation (MST) adalah sebuah konsep yang peneliti ditawarkan untuk mengatasi masalah ketidakpastian lalu lintas di Kota Makassar dengan optimalisasi operasional BRT Mamminasata Kota Makassar yang didasari dengan pemanfaatan IT. Konsep MST yang peneliti ciptakan yakni sistem pembayaran dalam bentukMamminasata Card dan sistem controlling dalam bentuk Mamminasata App yang dilengkapi dengan Sistem Floating Car Data Models (FCD).
\end{abstract}

Kata kunci: BRT Mamminasata, Public Transportation, MST, Mamminasata App, Mamminasata Card

Abstract: Public transportation in Indonesia plays a very crucial part for the solution of the nation's
economy. It should provide people the freedom and mobility in their daily activity. Not to mention reducing
traffic congestion. In Makassar, South Sulawesi, Indonesia, however, public transportation such as buses
are still not used to the fullest potential as there are some operational problems. This paper focuses on
finding the solution in the optimization of public transportation, especially Bus Rapid Transit (BRT). The
operation of BRT in Makassar began in March 2014 known as Maminasata. The main problems with BRT
Maminasata lies with its unpredictable arrival time and its payment system. This research offers a solution
using android based application called Maminasata Apps. through the concept of Makassar Smart 
Transportation (MST). Since one of the main problems of BRT Maminasata is its unpredictable arrival time, the Maminasata Apps. can be used to predict the arrival time of BRT Maminasata at every bus stops and is accommodated with live tracking and live streaming feature; bus stop information; and tourism destination information. Another feature of Maminasata Apps. in MST is the rechargeable Maminasata card which function as a top-up e-money that can be done simply by attaching the card to the back of the cellular phone. With this new app. used in every Bus Rapid Transit in Makassar, it is hoped that public transportation will gain its popularity again in the community as it will give people transportation options to get to work, go to school, and even sight-seeing in a more reliable and convenient way.

Keywords: public Transportation, MST, Mamminasata apps, Mamminasata Card

\section{PENDAHULUAN}

Jumlah penduduk Kota Makassar mengalami peningkatan dari tahun ke tahun. Pada tahun 2011 jumlah penduduk sekitar 1.338 .663 juta jiwa, 2012 meningkat menjadi 1.487 .049 juta jiwa, dan pada tahun 2015 meningkat lagi menjadi 1.700 .571 juta jiwa dengan luas wilayah 175.8 $\mathrm{Km}^{2}$ (BPS Kota Makassar, 2015). Sebagai salah satu kota besar di Indonesia, pertumbuhan penduduk signifikan dengan kebutuhan masyarakat akan sarana prasarana khususnya dibidang transportasi yang dapat ditandai pada kepemilikan kendaraan pribadi yang mengalami peningkatan, misalkan pada tahun 2014 jumlah kepemilikian kendaraan pribadi yaitu sebanyak 2,783,130.00 dan pada tahun 2015 meningkat menjadi 3,000,029.00 (BPS Kota Makassar, 2015). Permasalahan lalu lintas yang disebabkan karena tingginya tingkat kendaraan maka muncul kebijakan pemerintah untuk menggunakan transportasi publik.

Intensitas penggunaan BRT Mamminasata di kota Makassar semakin hari semakin menurun terhitung mulai awal pengoperasian pada Maret 2014 hingga hari ini. Hal ini dibuktikan dengan rerata pendapatan kotor dari 30 unit BRT yang beroperasi hanya dapat memperoleh Rp2.819.000/ hari (Perum Damri Kota Makassar). Ini menunjukkan suatu signal bahwa terdapat masalah ketidakoptimalan operasi BRT Mamminasata yang disebabkan oleh kurangnya ketertarikan masyarakat untuk menggunakan transportasi BRT Mamminasata. Kurangnya ketertarikan ini terjadi utamanya karena BRT Mamminasata tidak berjalan sebagaimana mestinya atau sesuai konsep yang direncanakan diawal, dimana BRT adalah transportasi yang aman, efisien, nyaman dan tepat waktu. Selain itu, temuan lain yang diperoleh melalui riset observasi awal, timbulnya ketidakterarikan penggunaan BRT oleh masyarakat dipicu oleh ketidakpastian waktu tempu dan waktu tiba bus pada halte dan ketidakefisienan sistem pembayaran dan sistem controlling passanger pada BRT Mamminasata.

Dalam artikel ini akan dibahas solusi atas kedua masalah fundamental diatas yang menyebabkan ketidakefektifan operasional BRT Mamminasata Kota Makassar. Solusi yang ditawarkan dalam studi ini adalah penerapan konsep Makassar Smart Transportation dengan 
Jurnal Bisnis, Manajemen dan Informatika

menggunakan sistem IT pada Sistem controlling dan sistem pembayaran pada operasional BRT Mamminasata Kota Makassar.

\section{RUMUSAN MASALAH}

Permasalahan ketidakoptimalan dari penerapan BRT Mamminasata di kota Makassar yang disebabkan karena kurangnya ketertarikan Masyarakat, yang disebabkan karena tingginya tingkat ketidakpastian waktu tempu dan waktu tiba halte dan sistem pembayaran, maka dari itu kami mengangkat rumusan masalah

1. Solusi atas tingginya ketidakpastian waktu tempu dan waktu tiba BRT Mamminasata.

2. Solusi untuk sistem pembayaran yang belum optimal.

\section{TINJAUAN PUSTAKA}

\subsection{Restrukturasi Ekonomi Sektor transportasi}

Fenomena mencuatnya persoalan transportasi publik di kota-kota besar di Indonesia terkait dengan modernisasi dan kapitalisme. Pergeseran pola perilaku transportasi ditunjukan dengan munculnya isu non-motorize trasportation, kemudian pemerintah menerapkan sistem transportasi berkelanjutan yang lebih mudah terwujud yang berbasis pada penggunaan trasportasi umum. Restrukturasi sektor transportasi memberikan dampak besar terhadap perekonomian karena transportasi menyangkut mobilitas dan aksebilitas masyarakat.

\subsubsection{Transportasi}

Nasution (1996) mendeskripsikan transportasi sebagai pemindahan barang dan manusia dari tempat asal ke tempat tujuan. Terdapat tiga hal mendasar dalam kegiatan transportasi, yaitu muatan yang diangkut, tersedianya kendaraan sebagai alat angkut, dan terdapatnya jalan yang dilalui. Untuk itu dengan adanya pemindahan barang dan manusia tersebut, maka transportasi merupakan salah satu sektor yang dapat menunjang kegiatan ekonomi dan pemberi jasa bagi perkembangan ekonomi.

\subsubsection{Peran transportasi dalam pembangunan ekonomi}

Mengingat kegiatan dibidang transportasi berperan penting dalam distribusi barang dan jasa keseluruh pelosok tanah air dan antar Negara, maka transportasi merupakan salah satu komponen strategis dalam pemerataan dan pertumbuhan ekonomi, aliran pergerakan manusia dan barang, aliran informasi, aliran dana yang perlu di kelolah secara tepat dan akurat untuk memenuhi ketepatan waktu. Transportasi juga merupakan alat kemakmuran, pembangunan politik, sosial budaya pertahanan keamanan. Peran transportasi sebagai ‘jembatan' yang 
memfasilitasi seluruh kegiatan perekonomian dan logistik nasional, memberikan nilai tambah secara sosial ekonomi (increased social economic value).

\subsection{Bus Rapid Transit}

Bus Rapid Transit (BRT) atau Busway merupakan bus dengan kualitas tinggi yang berbasis sistem transit yang cepat, nyaman dan biaya murah untuk mobilitas perkotaan. Bus Rapid Transit (BRT) pada dasarnya mengakumulasikan karakteristik kinerja sistem transportasi kereta api modern. Satu sistem BRT bisa dikenakan biaya 4-20 lebih kecil dari Light Rail Transit (LRT) dan 10-100 kali lebih kecil dari system kereta api bawah tanah.

Istilah BRT muncul dari penerapan Amerika Utara dan Eropa. Namun konsep ini juga diadopsi diseluruh dunia dengan nama yang berbeda-beda seperti Hight-Capacity Bus System, High- Quality Bus Sistem, Metro Bus, Surface Metro, Express Bus Systems dan Busway System. Meskipun memiliki istilah yang bervariasi antara satu negara dengan negara lain, tetapi memiliki prinsip dasar yang sama seperti kualitas dan pelayanan kendaraan yang bersaing dengan transportasi umum lainya dengan biaya/tarif yang dapat terjangkau. Untuk kemudahan, istilah BRT atau Busway sering digunakan dalam mengembangkan sistem ini. Namun, diakui bahwa konsep dan istilah ini tidak diragukan lagi akan terus berkembang. Beberapa tulisan yang membantu menjelaskan pengertian BRT, seperti sebagai berikut:

BRT adalah suatu moda transportasi yang cepat yang mengkombinasikan kualitas transportasi kereta dan flesibilitas bus (Tomas, 2001). Adapun tujuan dari dibuatnya BRT yakni untuk mengubah pandangan masyarakat terhadap transportasi darat khususnya bus. BRT memiliki keunggulan dalam kenyamanan, keamanan, keselamatan, efesiensi waktu dan biaya. Selain itu, tarif yang terjangkau karena menggunakan tarif sama untuk jarak jauh maupun dekat. Dengan demikian diharapkan adanya peralihan penggunaan dari kendaraan pribadi ke BRT.

Tujuan diadakanya BRT mamminasata adalah untuk menciptakan sistem transportasi yang lebih baik. Dengan terciptanya sistem transportasi kota yang baik akan membantu mengurangi permasalahan tranpotrasi perkotaan seperti kecelakaan, kemacetan, dll. Penyediaan BRT dianggap efektif mengurangi kemacetan (Sari, 2011).

\subsection{Sistem IT yang digunakan}

Adapun rancangan teknologi yang digunakan terdiri atas Floating Card Data Models, Global Positioning System(GPS), layanan Peta Internet Google Maps, NPC, RFID.

\subsubsection{Floating Car Data models}

Floating car data models adalah sala satu metode yang memakan biaya murah dalan efektif, pendekatan FCD lokasi dan kelajuan kendaraan dapat dilihat secara langsung dari pengamatan 


\section{Jurnal Bisnis, Manajemen dan Informatika}

kendaraan yang mengambang dalam lalu lintas dan posisinya ditentukan dari sarana teknologi navigasi seperti Global Psitioning System (GPS). Dengan model ini dapat memantau lokasi dan kelajuan bus-bus di satu koridor setiap saat untuk memberikan informasi lokasi bus dan estimasi waktu kedatangan bus pada halte tersebut. Floating Car Data ini dikolaborasikan dengan Global Positioning System untuk melacak secara real time dimana posisi objek yang akan lacak tersebut. GPS adalah sistem navigasi yang memakai satelit untuk menampilkan posisi secara instan dan informasi waktu yang ada di hampir seluruh dunia.

\subsubsection{Global Positioning System (GPS)}

Untuk mendapatkan lokasi dari BRT Mamminasata, perangkat bergerak Android yang dioperasikan oleh sopir BRT yang akan mengirimkan lokasi keberadaan BRT dengan menggunaan GPS. Global Positioning System adalah sistem navigasi berbasis satelit yang mengirim dan menerima sinyal radio. Sebelum penerima GPS mendapatkan sinyal tersebut dan menyampaikan informasi pada pengguna. Dengan menggunakan teknologi GPS, pengguna dapat mengetahui lokasi, kecepatan, dan waktu selama 24 jam, pada kondisi cuaca apapun dimanapun di dunia secara gratis. Untuk perangkat bergerak Android lokasi pengguna dapat diperoleh melalui callback. Pengembang dapat mengindikasikan untuk mendapatkan perubahan daril location manager dengan memanggil request location updates, memberikan sebuah location listener. Location listener harus mengimplementasikan beberapa metode callback yang location manager panggil ketika lokasi pengguna berubah atau layanan berubah.

\subsubsection{Layanan Peta Internet Google Maps}

Pada saat pendistribusian permintaan layanan dari konsumen yang diterima oleh operator, seorang operator akan menawarkan layanan ini pada bus yang akan menuju ke halte tersebut. Pengukuran jarak terdekat antara bus BRT dan pelanggan menggunakan salahsatu fitur Google Maps yang disebut dengan distance matrix adalah sebuah layanan yang menyediakan perhitungan jarak waktu dari array (lintang dan bujur lokasi) tempat awal dan array tempat tujuan. Berdasarkan informasi yang didapat, diperoleh dari rute rekomendasi dari titik awal dan titik akhir, seperti yang sudah dihitung oleh Google Maps API, dan terdiri dari baris-baris yang berisi nilai durasi dan jarak dari tiap pasangan array.

\subsubsection{Radio Frequency Identification (RIFD)}

Teknologi Radio Frequency Identification (RFID) merupakan metode pengumpulan data identitas dan identifikasi secara otomatis menggunakan frekuensi radio. Sistem perangkat keras RFID terdiri dari dua elemen, yaitu readeriInterogator dan transponder/tag Contoh sebuah aplikasi RFID banyak di terapkan pada tiket busway.

\subsubsection{Near Field Comunication (NFC)}


NFC merupakan pengembangan dari Radio Frequency Identification (RFID). Perkembangan NFC ini merupakan penggabungan antara ponsel yang dilengkapi dengan chipset NFC. Ponsel ini nantinya dapat mengubah sistem pembayaran yang ada saat ini menjadi pembayaran yang lebih efisien dengan menggunakan NFC. NFC memiliki layanan, seperti melakukan transaksi pembayaran, pembelian tiket, sebagai identitas dan sebagai pengambilan data. NFC merupakan salah satu teknologi besar yang dapat menunjang banyak layanan, seperti transaksi pembayaran ticketing, pengambilan data dll. NFC memiliki kemampuan yang lebih dalam sebuah ponsel, seperti melakukan transaksi pembayaran dengan mudah, dengan menghubungkan antara perangkat yang memiliki NFC, dan tidak perlu digosok, hanya tinggal ditempelkan ketika melakukan transaksi pembayaran. NFC melakukan transaksi pembayaran yang lebih baik dari pada teknologi telpon seluler (SMS).

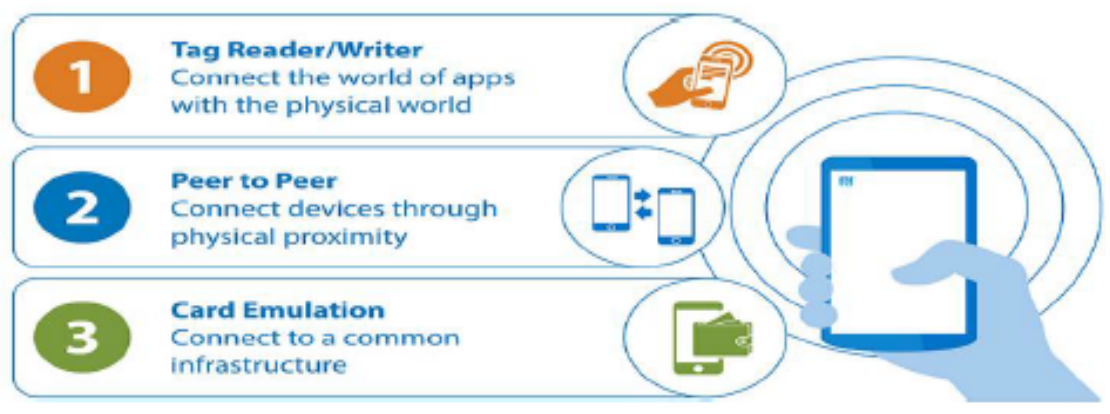

Gambar 1. Modes Operations dari NFC

Dari gambar diatas menunjukan cara kerja dari teknologi NFC itu sendiri pada penerapan Makassar Smart Transportation, khususunya pada sikronisasi antara Mamminasata Apps dan Mamminasta Card lebih banyak menggunakan fungsi Card Emulation, gambar di bawah ini adalah sinkronisasi phone dengan card yang dilengkapi dengan NFC.

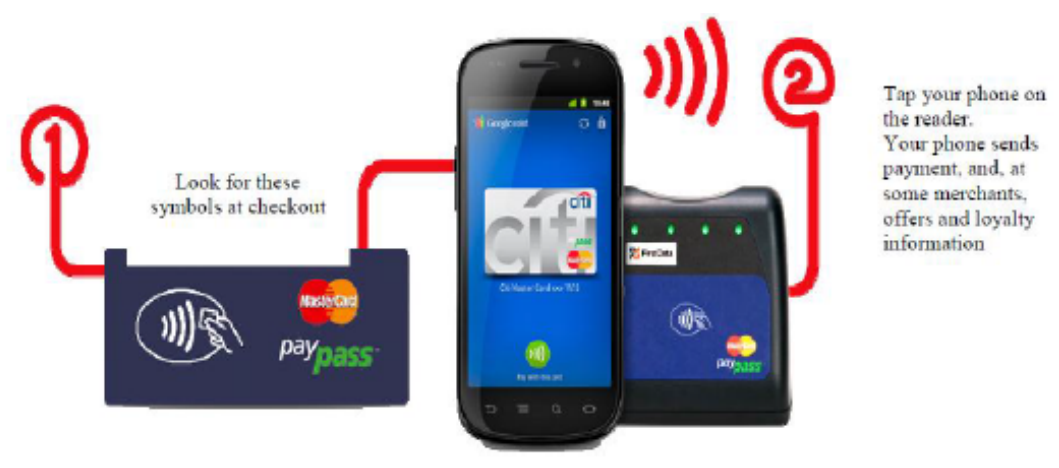

Gambar 2. NFC dan Card 

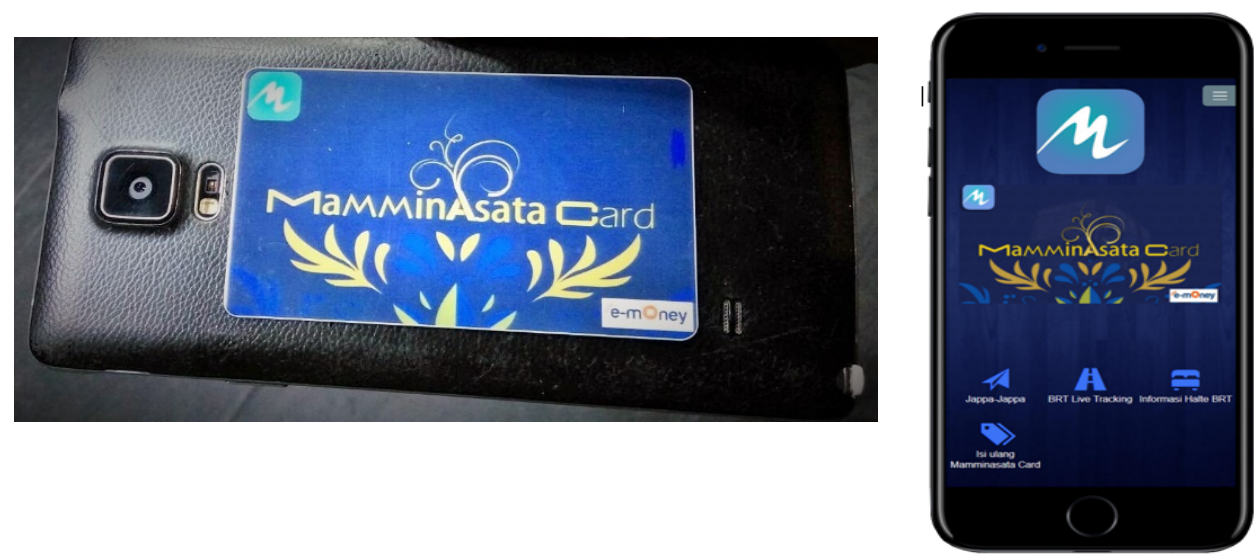

Gambar 3. Prototype Mamminasta Card dan Mamminasata Apps

\subsection{Manajemen Pembayaran dan Ticketing}

Pembayaran dan aplikasi ticketing adalah salahsatu alat untuk menciptakan standar pengguna NFC. Bank dan operator jaringan melakukan penelitian dan menemukan bahwa 89\% dari para pengguna yang melakukan transaksi berbasis ponsel lebih disukai karena kenyamanan metode pembayaran dan lebih efisien. Diharapkan nantinya NFC dapat menggantikan sistem pembayaran kartu kredit, kartu debit dan prabayar yang bisa digunakan dalam bertransaksi. Dibawah ini adalah gambar integrasi NFC ke dalam mobile dan arus komunikasi.

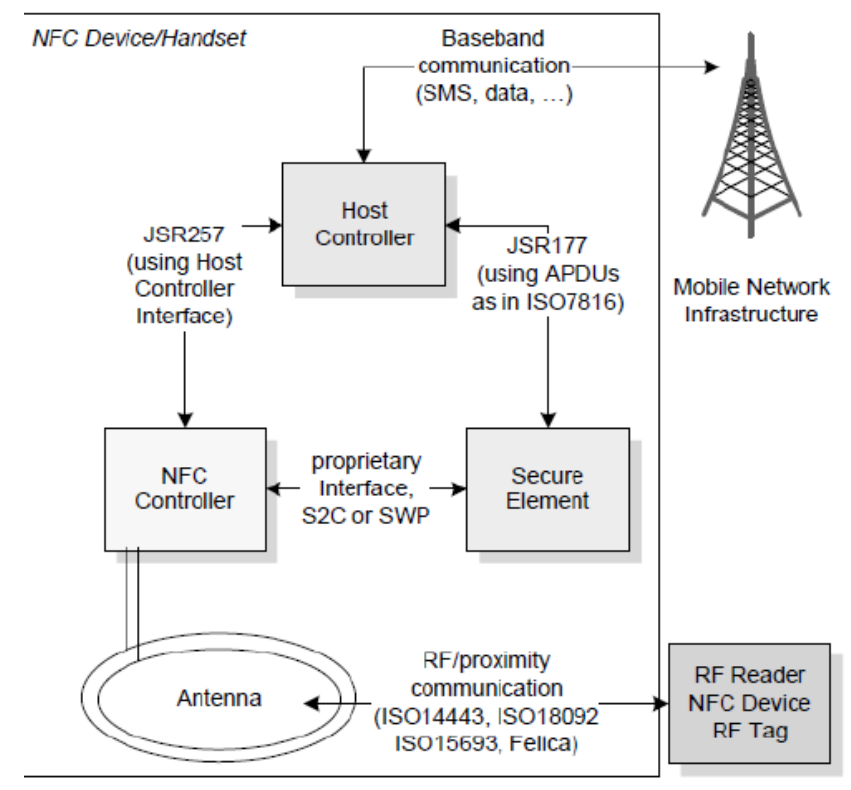




\section{Gambar 4. Integrasi NFC ke dalam Mobile dan Arus Komunikasi}

Tiket atau data pembayaran micro disimpan dalam perangkat yang aman pada NFC. NFC dapat menjadi contactless Smart Card dan juga menjadi ponsel untuk melakukan komukasi. Ketika pengguna akan melakukan transaksi pembayaran atau pengisian token pada $c a r d$, maka pengguna dapat memeriksa informasi yang dilakukan dan melakukan proses pembayaran atau pengisian token atau menolak. Gambar 5 menunjukan cara kerja NFC pada transaksi pembayaran atau pengisian token.

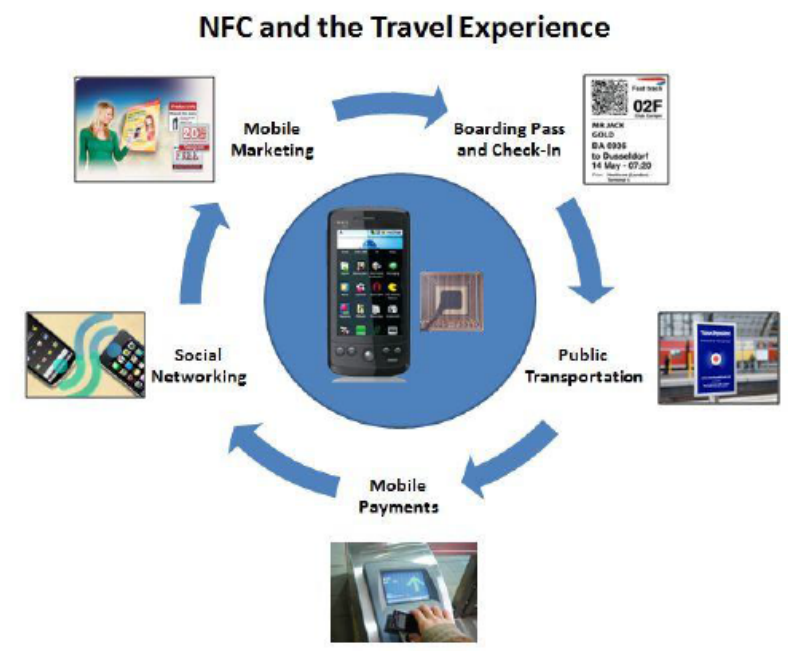

Gambar 5. Proses Kerja NFC pada Transaksi Pengisian Token

\subsection{E-Payment System}

E-payment adalah computer based system yang mengizinkan pelanggan untuk membayar barang dan jasa secara electrik. Jenis-jenis dari pembayaran eliktrik terdiri dari 3 yaitu:

a. Electonic checks adalah sebuah pengiriman elektronik dari dana-dana yang mana uang diambil dari rekening bank, seperti rekening giro sebagaian besar digunakan dalam B2B.

b. Eelektronic credit card adalah mengizinkan pelanggan untuk biaya pembayaran online untuk rekening kartu kredit mereka. Electronic credit card digunakan biasanya dalam B2C dan dalam pembelian oleh perusahaan kecil sampai menengah (SMEs).

c. Purchasing Card adalah kartu pembayaran yang macamnya digunakan untuk B2B pembayaran yang tidak terencana dan perusahaan pada umumnya terbatas jumlah perpembayaranya kartu pembayaran dapat digunakan pada internet seperti cash electronic ( $E$ cash) munculnya empat bentuk utama seperti stored-value money cards, smart card, person to persondan electronic cash.

\section{METODE PELAKSANAAN}




\section{Jurnal Bisnis, Manajemen dan Informatika}

Penelitian ini menggunakan pendekatan kualitatif berupa analisis deskriptif adapun data yang digunakan adalah data primer, kami melakukan observasi langsung kepada masyarakat dan penumpang dari BRT Mamminasata. Selanjutnya lokasi penelitian ini adalah Kota Makassar.

\section{PEMBAHASAN DAN HASIL}

\subsection{Makassar Smart Transportation}

Makassar Smart Transportation (MST) merupakan konsep yang kami tawarkan yang merupakan salah satu konsep atau wujud adanya restrukturisasi pada transportasi publik yang ada di Indonesia khususnya Makassar. Dengan penerapan IT pada transportasi publik penggunaan transpportasi publik dapat dimaksimalkan dan kebijakan pemerintah untuk menerapkan sistem transportasi berkelanjutan dapat tercapai.

Konsep ini ditawarkan untuk menyelesaikan permasalahan lalu lintas khususnya pada transportasi publik dalam hal ini BRT Mamminasata di kota Makassar. Berdasarkan hasil observasi yang telah kami lakukan menunjukan bahwa terdapat dua persoalan yang serius yaitu pertama kurangnya ketertarikan masyarakat untuk menggunakan BRT Mamminasata disebabkan karena tingkat ketidakpastian waktu tempu dan waktu tiba pada halte. Dan masalah kedua adalah sistem pembayaran dan ticketing yang belum efisien karena masih menggunakan pembayaran dan ticketing yang konevsional. Makassar Smart Transportation (MST) terdiri atas dua konsep yakni Mamminasata Apps sebagai aplikasi smartphone yang digunakan untuk mengontrol posisi BRT Mamminasata, berapa durasi dan waktu tempu hingga BRT tersebut tiba di halte. Kedua, Mamminasata Card adalah kartu yang digunakan untuk membayar ongkos atau tarif dari BRT Mamminasata.

\subsection{Mamminasata Apps}

Mamminasata Apps adalah aplikasi smartphone yang berguna untuk mengetahui posisi BRT Mamminasata sehingga memberikan kepastian waktu tiba BRT pada halte tertentu. Mamminasata Apps singkron dengan beberapa teknologi internet seperti Googlemaps, GPS, NFC dan RFID system. Mamminasata Appsmemiliki beberapa Fitur yakni livetracking, jappajappa, recharge token, informasi halte.

Fitur pertama adalahlivetrackingyang digunakan untuk mengetahui posisi BRT secara real time, yang di lengkapi dengan perkiraan durasi dan jarak. Fungsi ini di bantu dengan teknologi Global Positioning System (GPS). Live tracking ini dilengkapi dengan live streaming untuk melihat secara pasti kondisi jalan melalui video dengan bantuan CCTV. 


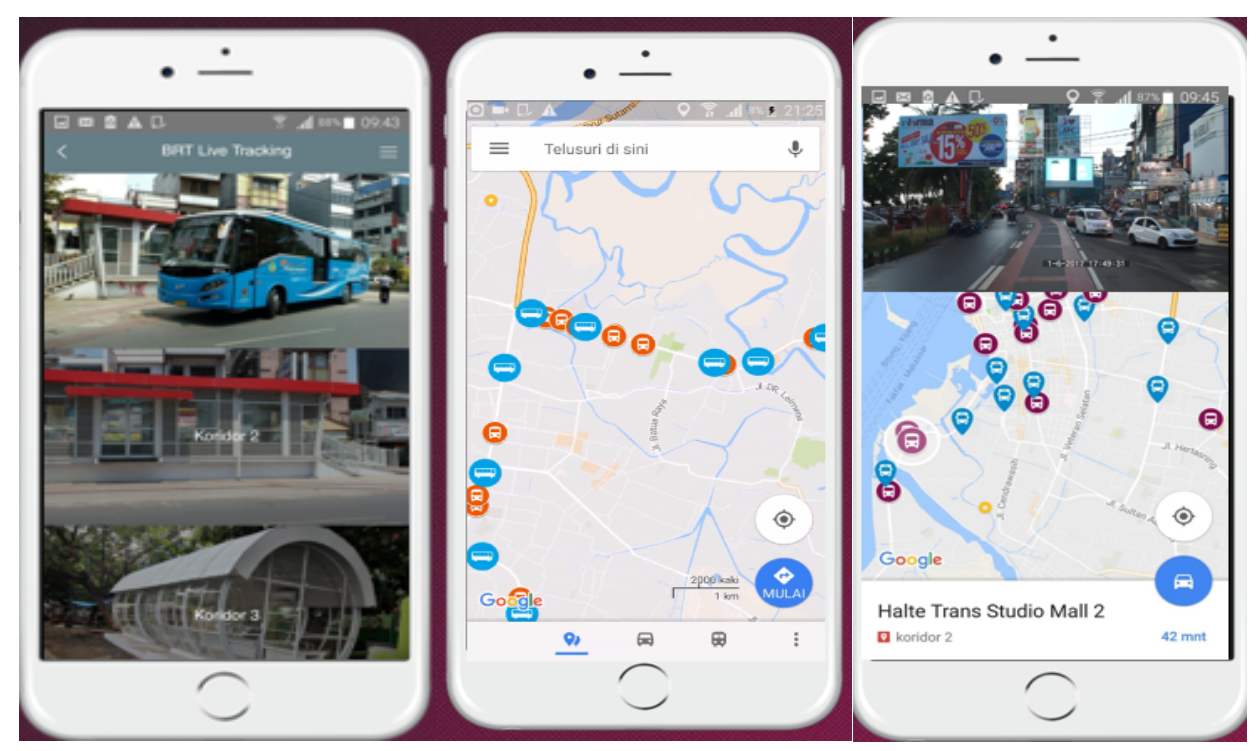

Gambar 6. Prototype Fitur Live Tracking

Fitur kedua diberi nama jappa-jappa. Fitur ini memberikan informasi mengenai tempat wisata disekitar koridor yang dilewati oleh BRT Mamminasata Kota Makassar, baik tempat wisata, tempat makan khas Sulawesi Selatan atau tempat yang menjadi icon kota Makassar.

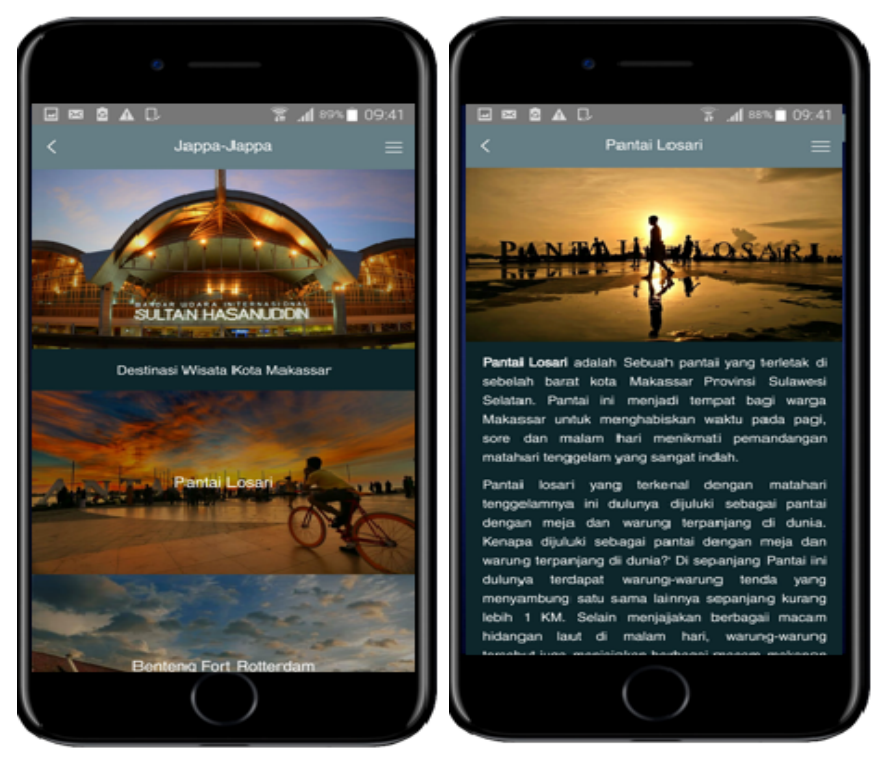

Gambar 7. Fitur Jappa-Jappa

Selanjutnya, fitur Re-Charge Token memiliki kemudahan melakukan pengisian ulang karena memiliki integrasi dengan sistem pembayaran yang kami tawarkan yakni Mamminasata card. Pengisian token card dapat dengan mudah dilakukan dengan menemplekan card pada bagian belakang telephone. Secara langsung akan terbuka Mamminasata Apps dan kemudian pilih nominal yang diinginkan. 


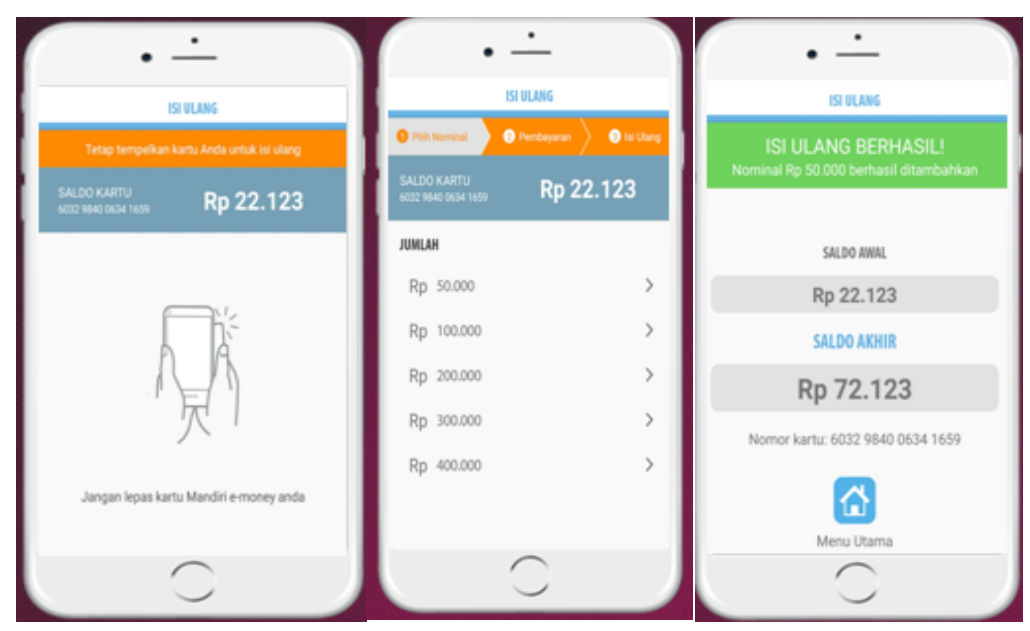

Gambar 8. Fitur Re-Charge Token Menggunakan E-Money

Fitur terakhir yakni merupakan informasi halteyang dapat memberikan informasi kepada panumpang terkait rute setiap koridor dan BRT di masing-masing koridor.

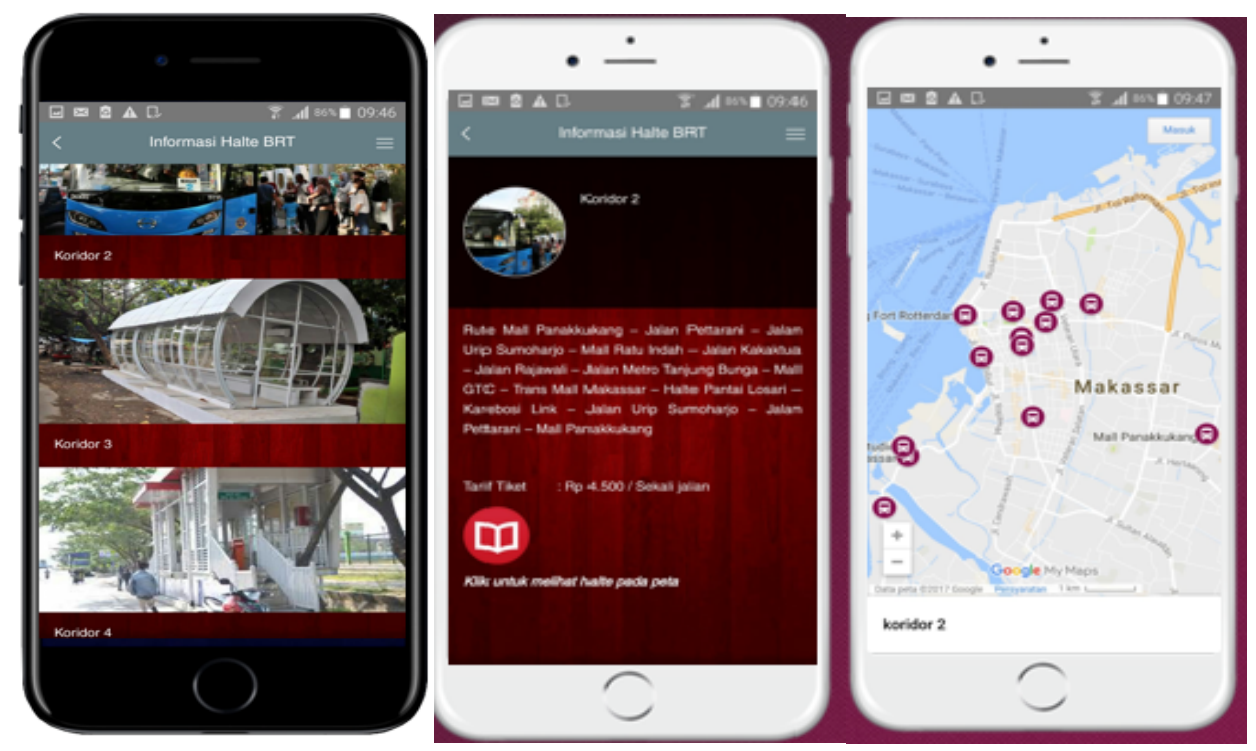

Gambar 9. Fitur Informasi Halte

Keempat fitur diatas merupakan fitur andalan dari Mamminasata Apps, untuk menyelesaikan permasalahn yang menjadi fokusan utama.

\subsection{Mamminasata Card}

Mamminasata Card adalah sistem pembayaran yang berbasis E-Money dan NFC yang di gunakan dalam pembayaran tarif pada BRT Mamminasata. Mamminasata card ini diciptakan dengan disingkronkan dengan RFID yang telah dimiliki oleh bank rekanan dan di bangun dengan sinkronisasi dengan NFC sehingga bisa melakukan pengisian token via telpon. Mamminasata card merupakan solusi yang kami tawarkan untuk menyelesaikan permasalah 
ketidakefisienan pembayaran pada BRT Mamminasata yang dapat memberikan celah kepada petugas atau staf untuk melakukan KKN (kolusi, korupsi dan nepotisme).

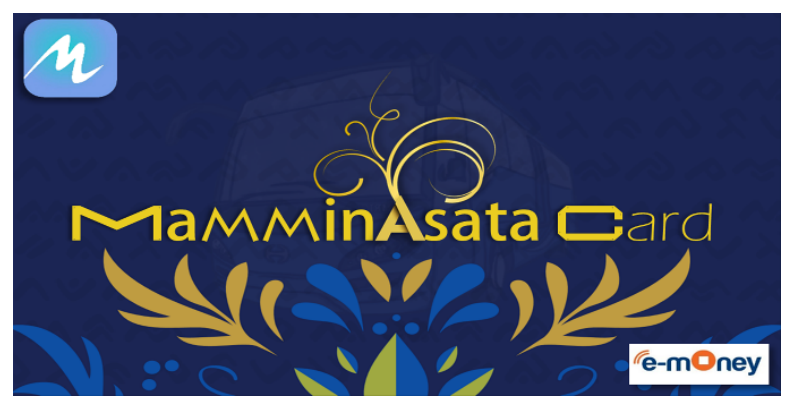

\section{Gambar 10. Mamminasata Card}

Mamminasata Card dapat di operasikan dengan menempelkan kartu pada mesin scanner yang di pasang pada setiap BRT nantinya. Sehingga sistem pembayaranya berbasis smartcard yang di lengkapi dengan E-Money. Solusi ini juga mendukung kebijakan Bank Indonesia untuk menjalankan gerakan non tunai di seluruh Indonesia. Untuk melakukan pengisian token Mamminasata card, cukup dengan menempelkan card pada telpon yang telah di lengkapi dengan NFC, makaakan terjadi proses pengisian token pada card. Mamminasata Card dan Mamminasata Apps memiliki keterhubungan yang erat, karena dalam Mamminasata Apps terdaat fitur untuk melakukan pengisian saldo atau token MamminasataCard, sehingga memberikan kemudahan kepada pengguna.

\section{PENUTUP}

Makassar Smart Transportation yang merupakan konsep yang kami tawarkan berupa penerapan IT berbasis Android dengan didukung penggunaan sistem teknologi lainya seperti RIFD, NFC, GPS, dan CCTV yang kami hadirkan untuk menyelesikan permasalahan ketidakpastian waktu tempu dan waktu tiba BRT pada halte dan masalah tidak efektifnya sistem pembayaran dan sistem ticketing serta pengendalian penumpang pada BRT Mamminasata. Makassar Smart Transportation terdiri dari Mamminasata Apps dan Mamminasata card.

Mamminasata Apps merupakan aplikasi berbasis smartphone yang berguna untuk controlling dimana posisi BRT dan berapa lama perkiraan durasi jarak tempu BRT menuju halte tertentu. Mamminasata Apps dilengkapi dengan beberapa fitur menarik yang akan menyelesaikan masalah ketidakpastian yang sering dirasakan oleh penumpang yang menyebabkan tidak tertariknya menggunakan BRT Mamminasata. Sementara itu, Mamminasatacard adalah smartcard yang berbasis E-money yang digunakan dalam pembayaran tarif atau ongkos ketika penumpang menggunakan BRT Mamminasata. Sebagai 
Jurnal Bisnis, Manajemen dan Informatika

hasil, Mamminasata Card menefektifkan manajemen ticketing dan pengendalian penumpang dari BRT Mamminasata.

\section{SARAN}

Untuk penelitian selanjutnya kami menyarankan untuk melihat aspek sosial, karena penerapan dari aplikasi yang kami tawarkan ini jika tidak diketahui iklim dan kondisi sosial dan budaya masyarakat maka akan kurang efektif. Permasalahan yang mendasar dalam persoalan transportasi adalah adalah masalah budaya dan perilaku masyarakat. Maka dari itu kami menyarankan jika ingin melanjutkan penelitian ini maka masukan unsur budaya masyarakat dan pola perilaku masyarakat dalam menggunakan teknologi.

\section{DAFTAR PUSTAKA}

Aida,A. dan Jesuk Ko.(2013). Real Time Road Traffic Management UsingFloating Cardata. International Journal of Fuzzy Logic and IntelegesiaSystem. 13(4). 269-276.

Ciptaningrum, M.S.(2016).Analisis Kinerja Jalan Raya Kota Malang Menggunakan Metode FCD (Floating Car Data). JNTETI. 5(1).

Departemen Pekerjaan Umum dan JICA. (2006). Rencana Tata Ruang Terpadu Untuk Wilayah Metropolitan Mamminasata. JICA.Makassar.

Dinas Perhubungan Provinsi Sulawesi-Selatan. (2014). Perencanaan Bus Rapid Transit. Makassar.

Hukmi,(n.d).Pengembangan Prasarana Feeder Menuju Halte Koridor 2 Bus Rapid Transit (BRT) Mamminasata.

Hemawan, D. dkk. (2012). Perencanaan Program Bus Rapid Transit Di kota Bandar Lampung. Jurnal Ilmu Administrasi FISIP.Unila.

International Transport Forum, Forum Highlights. "Transport for Global Economic". OECD/ITF 2009. https://www.oecd.org/sti/ind/1947035.pdf. Diakses 15/5/2017

Kenanthus, T.A.P. (2013).Analisis Preferensi Masyarakat Terhadap Bus rapid Transit (BRT) Semarang. FEB-Undip.

Nasrulloh, M.(2010.) Sistem Bus Metro.Fakultas Teknik, Universitas Indonesia.

Silondae, S., dkk. (2016). Keterkaitan Jarur Transportasi Dan Interaksi Ekonomi Kabupaten Konawe Utara Dengan Kabupaten Kota Sekitarnya. Jjurnal Progress Ekonomi Pembangunan. 1(1). 